\title{
EFFECT OF NURSE THERAUPETIC COMMUNICATION ON SATISFACTION AMONG THE FAMILIES OF SCHIZOPHRENIC PATIENTS AT PROF MUHAMMAD ILDREM MENTAL HOSPITAL, MEDAN, NORTH SUMATRA
}

\author{
Maria Haryanti Butarbutar1), Ihsan Kurniawan'), Naomi Hutabarat3), \\ Linda Hernike Napitupuluh3), Agnes Ferusgel3) \\ 1)Academy of Nursing Helvetia, Medan, Sumatra Utara \\ 2)Academy of Midwifery Helvetia, Medan, Sumatra Utara \\ 3)Helvetia Institute of Health, Medan, Sumatra Utara
}

\begin{abstract}
Background: Therapeutic communication is the primary component of all health care interaction that facilitates the development of positive clinician-patient experiences. Nurses with the skills to communicate not only will be easily establish a trusting relationship with the patients but also patients' families. Therapeutic communication is known to be necessary for quality healthcare and increase patient satisfaction. This study aimed to examine the effect of nurse therapeutic communication on satisfaction among the families of schizophrenic patients at Prof Muhammad Ildrem Mental Hospital, Medan, North Sumatra.

Subjects and Method: This was a cross-sectional study conducted at Prof Muhammad Ildrem Mental Hospital in Medan, North Sumatera. A sample of 150 families of schizophrenic patients was selected for this study. The independent variable was nurse therapeutic communication. The dependent variable was satisfaction among the families of schizophrenic patients. The data was collected by a set of questionnaire and analyzed by a linier regression.

Results: Satisfaction among the families of schizophrenic patients increased with good nurse therapeutic communication ( $b=0.01 ; p=0.005)$

Conclusion: Satisfaction among the families of schizophrenic patients is associated with nurse therapeutic communication.
\end{abstract}

Keywords: satisfaction, schizophrenic, patients, nurse, therapeutic, communication.

\section{Correspondence:}

Maria Haryanti Butarbutar. Academy of Nursing Helvetia, Medan, North Sumatra. Jl. Kapten Sumarsono No.107 Medan. Email: Maria_haryanthi@yahoo.com.au, mariaharyanti@helvetia.ac.id. Mobile: 081361518151.

\section{BACKGROUND}

Waste and its management are now an urgent problem in Indonesia. If no proper handling is carried out, it will result in adverse or unpredictable changes in the environmental balance that can pollute the environment both for soil, water and air (Ministry of Health, 2009).

According to Law No. 18/2008, waste management is defined as a systematic, comprehensive and sustainable activity that includes the reduction and handling of waste. Waste can cause disturbance to humans as well as ecology and natural resources, so it needs adequate efforts to get a good waste disposal system (Ministry of Health, 2009).

Part of Indonesia as the largest producer of waste is the Province of West Java, followed by East Java, Central Java, North Sumatra and DKI Jakarta, making Java the largest waste producing island in Indonesia. Waste generated is dominated by household waste and some of it is food waste. Household waste produced reaches $1.12 \mathrm{~kg} /$ capita every day, food waste dominates $58 \%$ of the total household waste. The scope of waste handling by the Government is felt to be very low. 
Garbage collected by cleaners in Indonesia is only around $\mathbf{1 6 . 7}$ million tons per year. On the other hand, rubbish that is not collected by related service officials counts around 116 million tons per year, the difference is very significant. This happens because there are still many Indonesian citizens who have not been served by waste management services (Ministry of Environment, 2018).

Study conducted by Ramadhani (2014) entitled "Medan City Waste Management Study" shows that waste in the loyal market, consisting of $68.90 \%$ organic waste and $31.10 \%$ inorganic waste, from this amount has the potential to be processed waste into compost and various types of handicrafts that are economically valuable. Based on the results of the study, it can be concluded that, waste in the Setia Budi market has the potential to be managed, and it is feasible to establish a compost processing facility (Ramadhani, 2014).

Study conducted by Sari and Safrudin (2016) entitled "The Role of the Sanitation Office in the Management of Household Waste in TPA Terjun, Medan Marelan Subdistrict" shows that this has not been maximized and there are some deficiencies externally, for example, the location of funds provided by the central government very minimal because the cost is used to replace old equipment (Sari and Ritonga, 2016).

The initial survey conducted by authors showed that the waste management in Nelayan Indah Village, Medan Labuhan Subdistrict was not very organized, this was seen because there were not yet available Temporary Disposal Sites (TPS), so that the community simply threw away their garbage. Data taken from the results of interviews with 10 households revealed that 4 households in their houses had garbage bins but the community did not throw rubbish in its place directly thrown into the sea, while 6 households did not have trash bins but the garbage was burned and some threw it into the sea at during high tides.

The location that borders the sea makes endless garbage in the area so it is very vulnerable to the development of diseases such as diarrhea, typhus, vomiting and so on. Many children in this environment suffer from diarrhea. Based on interviews conducted by the authors it can be concluded that the public does not know how to collect waste properly and how to manage it. The people of Nelayan Indah Village, Medan Labuhan Subdistrict have not yet managed their waste, they only dispose of garbage around the house and disposed of to the sea.

Based on the survey results above, authors are interested in conducting study with the title "Factors Affecting Household Waste Management in Nelayan Indah Village, Medan Labuhan District".

\section{METHOD}

\section{Study Design}

This study is a quantitative study with a survey method through a cross sectional approach which is a study to study the dynamics of correlation by approaching, observing or collecting data at one time (point time approach). This study was conducted in Belawan Nelayan Indah Village, Medan Labuhan District, from March to July 2019.

\section{Population and Sample}

The population of this study was 2013 heads of families in the Nelayan Indah Village, Medan Labuhan District. The sample in this study was 95 households in Nelayan Indah Village, Medan Labuhan District. Samples were taken using the Slovin formula. The number of samples is 95 respondents and then determined the number of each sample according to villages in each neighborhood by proportionate random sampling.

\section{Data Analysis}

Analysis of the data used in this study is univariate analysis, which is the analysis used 
for each variable that describes the frequency distribution of each variable. Bivariate analysis is an analysis carried out to prove the existence of a significant relationship between the independent variable and the dependent variable through cross tabulation of data analysis with the chi-square statistical test.

\section{RESULTS}

\section{Characteristics of Respondents}

Table 1 shows the frequency distribution of respondents in Kelurahan Nelayan Indah, Medan Labuhan District.

\section{Table 1. Characteristics of Respondents}

\begin{tabular}{|c|c|c|}
\hline Characteristics of Respondents & f & Percentage (\%) \\
\hline \multicolumn{3}{|l|}{ Gender } \\
\hline Male & 45 & 47,4 \\
\hline Female & 50 & 52,6 \\
\hline \multicolumn{3}{|l|}{ Age } \\
\hline 30-37 years & 30 & 31.6 \\
\hline $38-45$ years & 29 & 30.5 \\
\hline 46-53 years & 26 & 27,4 \\
\hline 54-61 years & 5 & 5,3 \\
\hline $62-70$ years & 5 & 5,3 \\
\hline \multicolumn{3}{|l|}{ Education } \\
\hline No formal school & 30 & 31.6 \\
\hline PS & 21 & 22,1 \\
\hline JHS & 23 & 24,2 \\
\hline SHS & 11 & 11.6 \\
\hline Diploma/Bachelor & 10 & 10.5 \\
\hline \multicolumn{3}{|l|}{ Occupation } \\
\hline Civil Servant & 9 & 9,3 \\
\hline Entrepreneur & 10 & 10.3 \\
\hline Labor & 12 & 12,4 \\
\hline Sailor & 43 & 44,3 \\
\hline Housewife & 22 & 22,7 \\
\hline \multicolumn{3}{|l|}{ Income } \\
\hline$<$ Rp. 2.500.000 & 54 & 56,8 \\
\hline$\geq$ Rp. 2.500 .000 & 41 & 43,2 \\
\hline \multicolumn{3}{|l|}{ Type of House } \\
\hline House on stilts & 52 & 54,7 \\
\hline Regular house & 43 & 45,3 \\
\hline
\end{tabular}

\section{Univariate Analysis}

Table 2. discusses the frequency distribution of respondents based on knowledge from 95 respondents, 24 people in the good category (24.7\%), 21 people are in the moderate category (21.6\%), and 50 people fall into the poor category (51.6\%).

Frequency distribution of respondents based on attitude, out of 95 respondents, 22 people fall into the good category (22.7\%), 25 people fall into the adequate category (25.8\%), and 48 people fall into the poor category (49.5 \%). Furthermore, the frequency distribution of respondents is based on the availability of facilities and infrastructure, of the 95 respondents, 51 people fall into the category not available (53.7\%), and 44 people fall into the available category (46.3\%). The frequency distribution of respondents is based on waste management, of the 95 respondents, 55 people fall into the unmanaged category (55.8\%), and 42 people fall into the managed category (44.2\%). 
Table 2. Univariate Analysis

\begin{tabular}{lll}
\hline Variable & Frequency (f) & Percentage (\%) \\
\hline Knowledge & & \\
Good & 24 & 24,7 \\
Fair & 21 & 21.6 \\
Poor & 50 & 51.5 \\
\hline Attitude & 22 & 22,7 \\
Good & 25 & 25.8 \\
Fair & 48 & 49,5 \\
Poor & & \\
Availability of Facilities and & & \\
Infrastructure & 44 & 46.3 \\
Available & 51 & 53.7 \\
Unavailable & & \\
Waste Management & 44 & 44.2 \\
Managed & 55 & 55.8 \\
Unmanaged &
\end{tabular}

\section{Bivariate Analysis}

Table 3 shows the results of the chi square test results obtained that knowledge $(\mathrm{p}=$ o.042), attitude ( $\mathrm{p}=0.036)$, and facilities and infrastructure (0.024) related to waste management activities in Nelayan Indah Village, Medan Labuhan District.

Table 3. The Relationship of Knowledge, Attitudes, Availability of Facilities and Infrastructure with Waste Management in Nelayan Indah Village, Medan Labuhan District

\begin{tabular}{|c|c|c|c|c|c|c|c|}
\hline \multirow{3}{*}{ Variables } & \multicolumn{7}{|c|}{ Waste Management } \\
\hline & \multicolumn{2}{|c|}{ Managed } & \multicolumn{2}{|c|}{ Unmanaged } & \multicolumn{2}{|c|}{ Total } & \multirow[b]{2}{*}{$\mathbf{p}$} \\
\hline & $\mathbf{f}$ & $\%$ & $\mathbf{f}$ & $\%$ & $\mathbf{f}$ & $\%$ & \\
\hline Knowledge & & & & & & & 0.042 \\
\hline Good & 6 & 25.0 & 18 & 18,9 & 24 & $25 \cdot 3$ & \\
\hline Fair & 13 & 13.7 & 8 & 8.4 & 21 & 22.1 & \\
\hline Poor & 23 & 24.2 & 27 & 28.4 & 50 & 52.6 & \\
\hline Attitude & & & & & & & 0.036 \\
\hline Good & 16 & 16.8 & 6 & 6.3 & 22 & 23.2 & \\
\hline Fair & 9 & 9,5 & 16 & 16.8 & 25 & 26.3 & \\
\hline Poor & 28 & 29.5 & 20 & 21.1 & 48 & 50.5 & \\
\hline $\begin{array}{l}\text { Availability of facilities } \\
\text { and Infrastructure } \\
\text { Available }\end{array}$ & 14 & 14.7 & 30 & 31.6 & 44 & 46.3 & 0.024 \\
\hline Unavailable & 28 & 29.5 & 23 & 24.2 & 51 & 53.7 & \\
\hline
\end{tabular}

\section{DISCUSSION}

\section{The Effect of Knowledge on Waste}

\section{Management}

Based on the results of the study, it can be stated that there is a relationship between knowledge and waste management in Nelayan Indah Village, Medan Labuhan District.
Knowledge is the result of knowing and occurs after people sensing a certain object. Knowledge takes place through the five senses of sight, hearing, smell, taste and touch. Most of human knowledge is gained through the eyes and ears. Knowledge theory is related to sources of knowledge (Notoatmojo, 2011) 
Knowledge is very important, because knowledge makes us think long and makes us avoid the same mistakes. Broad insight, can improve the ability to think critically so difficult problems can be more easily solved (Notoatmojo, 2010).

This study is in line with Rahmadani (2017) with the title Factors Affecting Household Waste Management in the Village Village of Johan Pahlawan, West Aceh District. Chi square test results showed a significant relationship between knowledge and trader participation with a $\mathrm{p}$ value of $0.0001<0.05$, indicating a meaningful relationship between attitudes and trader participation with a $\mathrm{p}$ value of 0.00010 .05 and between the availability of facilities with trader participation also showed a significant relationship with $\mathrm{p}$ value $0.0001<0.0005$ (Rahmadani, 2017)

This study is also in line with Setyowaty (2013), with the title Knowledge and Behavior of Housewives in Plastic Waste Management in Kedesen Hamlet, Kradenan Village, Kaliwungu District, Semarang Regency. The results of the study stated that $56.8 \%$ of respondents had poor knowledge and around $60.8 \%$ of respondents behaved badly. The results of this study indicate that there is a very significant relationship between the level of knowledge of housewives with the behavior of managing plastic waste in Kedesen Hamlet, Kradenan Village, Kaliwungu District, Semarang Regency (Setyowati, 2013).

This study is also in line with Sari and Mulasari in (2017) with the title Knowledge Relationship, Attitudes and Education with Waste Processing Behavior in Bener Village, Tegalrejo District, Yogyakarta. Based on the results of study conducted on 81 respondents obtained the results that there is no relationship between knowledge of attitudes and education with waste processing behavior in the Village of Bener, Tegalerejo District, Yogyakarta.
Based on the results, the authors concluded that the community's knowledge in the Nelayan Indah Village was not good. From observations, it can be seen that in the Nelayan Indah Kelurahan Medan Labuhan there were no billboards, posters, stickers or slogans about invitations to provide and dispose of rubbish in its place, also about the health hazards of the rubbish.

The public does not know that waste generated from household waste must be sorted out between organic waste and nonorganic waste before disposal. People do not know and do not care if the garbage is carelessly disposed of and not managed properly can make their environment a den or a breeding place for disease vectors. The community is also less aware that in fact nonorganic waste can be collected and sold for recycling as additional family income so that the economy/ family income can be further increased.

\section{The Effect of Attitude on Waste Management}

Based on the results of this study, attitudes are associated with waste management in Nelayan Indah Village, Medan Labuhan District.

According to one social psychologist, Newcomb, states that attitude is readiness or willingness to act and is not an implementation of certain motives. In other words the attitude function is not an action (open reaction) or activity, but it is a predisposing behavior (action) or closed reaction (Setyowati, 2013).

This study was in line with Sumah et al (2013), with the title Relationship Between Knowledge and Attitudes with Actions of Housewives in the Management of Household Waste in Environment II Istiqlal Village, Wenang Subdistrict, Manado City. It was indicate that knowledge and attitudes are related to the actions of housewives in managing household waste 
Similar study was also conducted by Yeni (2013), with the title Factors Affecting Household Waste Management in the Village Village of Johan Pahlawan District, West Aceh, the results showed that knowledge and attitudes had a relationship with household waste handling so that there was a significant relationship between knowledge and attitude with the handling of household waste in Gampong Darat Village, Johan Pahlawan District, West Aceh.

Mahyudin in (2014) examined the Relationship between Knowledge and Community Attitudes with Waste Management in the Village of Deli Loli Tasiburi, Benawa District, Donggala Regency. It stated that there is a relationship between knowledge and attitude with waste management in the community of Deli Loli Tasiburi village (Syam, 2016).

The results of this study stated that attitudes are influential with waste management. People who have a positive attitude tend to take actions to manage waste properly, people with a positive attitude already have a basis for taking positive actions as well. The people in Nelayan Indah Village, Medan Labuhan Subdistrict, said that throwing trash from around the house means that they have taken good waste management actions, even though the garbage is thrown away into the sea water, but some say that they sometimes throw garbage into the sea because they are in a hurry.

Some of them work as factory workers who do not have much free time at home because they leave for work in the morning and return home in the afternoon, sometimes not returning because of overtime. The community does not know that a positive attitude will form a commitment to take good waste management actions.

\section{The Effect of Facilities and Infra- structure on Waste Management}

Based on the results of the study, authors found that there was an influence of facilities and infrastructure on waste management in Nelayan Indah Village, Medan Labuhan District. Authors saw that the environment in the Medan Labuhan sub-district of Nelayan Indah was not available with good trash.

In the houses there are no permanent bins, they collect rubbish only in old plastic bags used for shopping. The community said that they did not need to provide permanent rubbish bins because they could dump directly into the sea. In their neighborhood, in the alleys/ roads there is also a lack of temporary rubbish bins (TPS) so that they and their children throw garbage away. Besides they often throw rubbish into the sea, they also often throw rubbish into this ditch because the polling station is not present on almost every road so authors see that the sewage in the environment is clogged with garbage.

The people in the Nelayan Indah Village, Medan Labuhan Subdistrict also assume that the waste problem is a government matter, they don't need to bother thinking about waste because the waste problem is the responsibility of the government.

The results of this study are in line with Rahman (2013) with the title Community Behavior in Household Waste Management. It is show that community behavior in applying general principles of waste management has been going well, but the application of the $3 \mathrm{R}$ principle is still not good. Constraints faced by the community include; 1 ) the community said that they had not been served by the pickup of their house, 2) the community said that there was no TPS available in their neighborhood. Constraints faced by the Government are: 1) Lack of facilities such as TPS, 2) Not all areas in Pasar Sarolangun Kelurahan can be served by Distaksiman, 3) Lack of Experts (Rahman, 2013). 
Likewise with Ramadhyan (2014), entitled The Relationship Between the Level of Knowledge of Housewives and the Attitude of Waste Management in Gampong Jawa, Kutaraja District, Banda Aceh. The results showed t count 9.338> t table 2.000, it can be concluded that, there was a significant relationship between the level of knowledge of housewives on the attitude of waste management in the Gampong Jawa District of Kutaraja Banda Aceh (Rahman, 2014).

\section{The Most Dominant Factor in Waste} Management

The most dominant factor influencing waste management is facilities and infrastructure. The community does not have a TPS so they throw trash directly into the sea because the location is in the borders of Belawan Sea.

\section{REFERENCES}

Ministry of Health (2009). Undang-Undang Republik Indonesia Nomor 36 tahun 2009 Tentang Kesehatan. Cardiol Clin. 2009; 27(1):xv-Xv.

Ministry of Environment (2018). Komposisi sampah Indonesia Berdasarkan Sumbernya 2008.

Notoatmodjo S (2010). Etika dan Hukum Kesehatan (Health Ethics and Law). Jakarta: Rineke Cipta; 2010.

Notoatmojo S (2011). Kesehatan Masyarakat Ilmu dan Seni (Public Health Sciences and Arts). Jakarta: Rineka Cipta. 2011. p. $135-66$.

Rahman A (2013). Perilaku Masyarakat dalam Pengelolaan Sampah Rumah Tangga (Studi Kasus di Kelurahan Pasar Sarolangun) (Community Behavior in Household Waste Management (Case Study in Pasar Sarolangun Village). J Bina Praja. 2013;5(4):21520.

Ramadhyan V (2014). Hubungan antara Tingkat Pengetahuan Ibu Rumah Tangga dengan Sikap Pengelolaan
Sampah di Gampong Jawa Kecamatan Kutaraja Banda Aceh (Relationship between Level of Knowledge of Housewives with Waste Management Attitudes in Gampong Jawa, Kutaraja District, Banda Aceh). Banda Aceh; 2014. Ramadhani A (2014). Studi Pengelolaan Sampah Pasar di Kota Medan (Market Waste Management Study in Medan City). Tek Sipil Univ Sumatera Utara.

Sari D, Ritonga S (2016). Peran Dinas Kebersihan Dalam Pengelolaan Sampah Rumah Tangga di TPA Terjun Kecamatan Medan Marelan (The Role of the Sanitation Office in the Management of Household Waste in TPA Terjun, Medan Marelan District). Univ Medan Area. 2016;4(1):65-73.

Rahmadani E (2017). Hubungan Pengetahuan, Sikap dan Ketersediaan Sarana Pengelolaan Sampah dengan Partisipasi Pedagang dalam Pengelolaan Sampah di Pasar Raya Solok Tahun 2017 (The Relationship between Knowledge, Attitude and Availability of Waste Management Facilities and Traders' Participation in Waste Management in Pasar Raya Solok in 2017).

Setyowati R (2013). Pengetahuan dan Perilaku Ibu Rumah Tangga dalam Pengelolaan Sampah Plastik (Knowledge and Behavior of Housewives in Plastic Waste Management). Univ Ahmad Dahlan.

Sumah (2013). Hubungan Antara Pengetahuan dan Sikap dengan Tindakan Ibu Rumah Tangga dalam Pengelolaan Sampah Rumah Tangga di Lingkungan II Kelurahan Istiqlal Kecamatan Wenang Kota Manado (The Relationship Between Knowledge and Attitudes with Actions of Housewives in the Management of Household Waste in Environment II Istiqlal Village, 
Wenang Subdistrict, Manado City). Phys Rev B. 2013; 72(10): 1-13.

Syam DM (2016). Hubungan Pengetahuan dan Sikap Masyarakat Dengan Pengelolaan Sampah di Desa Loli Tasiburi Kecamatan Banawa Kabupaten Donggala (Relationship between Knowledge and Community Attitudes with Waste Management in Loli Tasiburi Village, Banawa District, Donggala Regency).
Higiene. 2016; 2(1): 21-6.

Yeni, A (2013). Faktor-Faktor Yang Mempengaruhi Penanganan Sampah Rumah Tangga di Desa Gampong Darat Kecamatan Johan Pahlawan Aceh Barat Tahun 2013 (Factors That Influence Handling of Household Waste in Gampong Darat Village, Johan Pahlawan District, Aceh Barat District in 2013). 